\title{
Alloxan cytotoxicity is highly potentiated by plasma membrane- and lysosomal-associated iron - a study on a model system of cultured $\mathbf{J}-774$ cells
}

\author{
H.Zhang, U.T. Brunk \\ Department of Pathology II, Faculty of Health Sciences, University of Linköping, Linköping, Sweden
}

\begin{abstract}
Summary. Pancreatic islet beta cells, and some other cell types, are sensitive to the damaging effects of alloxan. The mechanisms behind the cytotoxicity have not been fully elucidated, although they are considered to be mediated by the formation and effects of reactive oxygen metabolites. In the present study, the cytotoxic effects of alloxan/cysteine at high and low concentrations were investigated on a model system of cultured J-774 cells. Viability was estimated by the trypan blue dye exclusion test, plasma membrane permeability by a modified microfluometric fluorescein diacetate technique and lysosomal membrane stability by a microfluorometric acridine orange method. The results showed: (a) hydrogen peroxide, readily diffusing through cellular membranes and produced extracellularly in large amounts by alloxan/cysteine at high concentrations, enters the secondary lysosomes if not previously degraded by cellular anti-oxidant systems. Intralysosomal Fenton reactions, with the formation of hydroxyl radicals, may be induced provided catalytically active lysosomal iron is present. This would result in lysosomal membrane damage followed by leakage of lysosomal contents to the cell sap and
\end{abstract}

cell degeneration. (b) Alloxan/cysteine at low concentrations induced production of superoxide and hydrogen peroxide in low amounts which caused almost no lysosomal damage and appeared to be non-toxic unless there was some plasma membrane-associated iron. Consequently, cells initially allowed to endocytose iron during culture, or briefly exposed to iron just before exposure to alloxan and cysteine, showed greatly enhanced sensitivity. In this case iron, in combination with superoxide and hydrogen peroxide, is believed to give rise to plasma membrane-associated hydroxyl radical production (Fenton reaction) with resultant loss of membrane integrity. We thus propose that reasons for pronounced alloxan sensitivity may include lysosomal damage to cells with weak anti-oxidative defense systems or especially vulnerable secondary lysosomes or ironcatalysed plasma membrane damage following exocytosis of this transition metal.

Key words: Alloxan, iron, plasma membrane, lysosomes, cultured J-774 cells.
The quinonoid compound alloxan is a rapid and potent inducer of diabetes mellitus in experimental animals due to its pronounced damaging effect on pancreatic islet beta cells [1-6]. Other cell types are also sensitive to the cytotoxic effect of alloxan, albeit to a varying and usually much lesser degree [7-14]. The exact mechanisms of alloxan cytotoxicity are not fully understood, although the toxicity is considered to be mediated by the formation and effects of reactive oxygen species such as superoxide anion radicals $\left(\mathrm{O}_{2}{ }^{--}\right)$, hydrogen peroxide $\left(\mathrm{H}_{2} \mathrm{O}_{2}\right)$ and hydroxyl radicals $\left(\mathrm{HO}^{\circ}\right)[4-7,12-27]$. A uniquely weak anti-oxidative defense system of beta cells has been suggested to underlie their sensitivity to oxidative stress [21,28], although this hypothesis has been challenged [29].

Alloxan is easily reduced to dialuric acid by a variety of reducing agents including cysteine, ascorbic acid and glutathione $[12,13,15,20,24,25]$. In the presence of oxygen, autooxidation of dialuric acid back to alloxan generates $\mathrm{O}_{2}{ }^{--}$, and the formation of alloxan radicals is part of both the reduction and autooxidation processes $[5,6,24,25]$.

In previous studies on a model system of cultured, established mouse macrophage-like J-774 cells [12-14] we presented evidence that alloxan cytotoxicity results from a dual effect of reactive oxygen metabolites formed extracellularly during alloxan reduction and autooxidation. In the present study we concentrated on the enhancing role of plasma membrane-associated iron. The cytotoxic mechanisms we propose, which do not necessitate cellular uptake of alloxan, include (i) $\mathrm{HO}^{*}$ attack at the plasma membrane level or (ii) diffusion of $\mathrm{H}_{2} \mathrm{O}_{2}$ through the cytoplasm into lysosomes where intralysosomal Fenton 

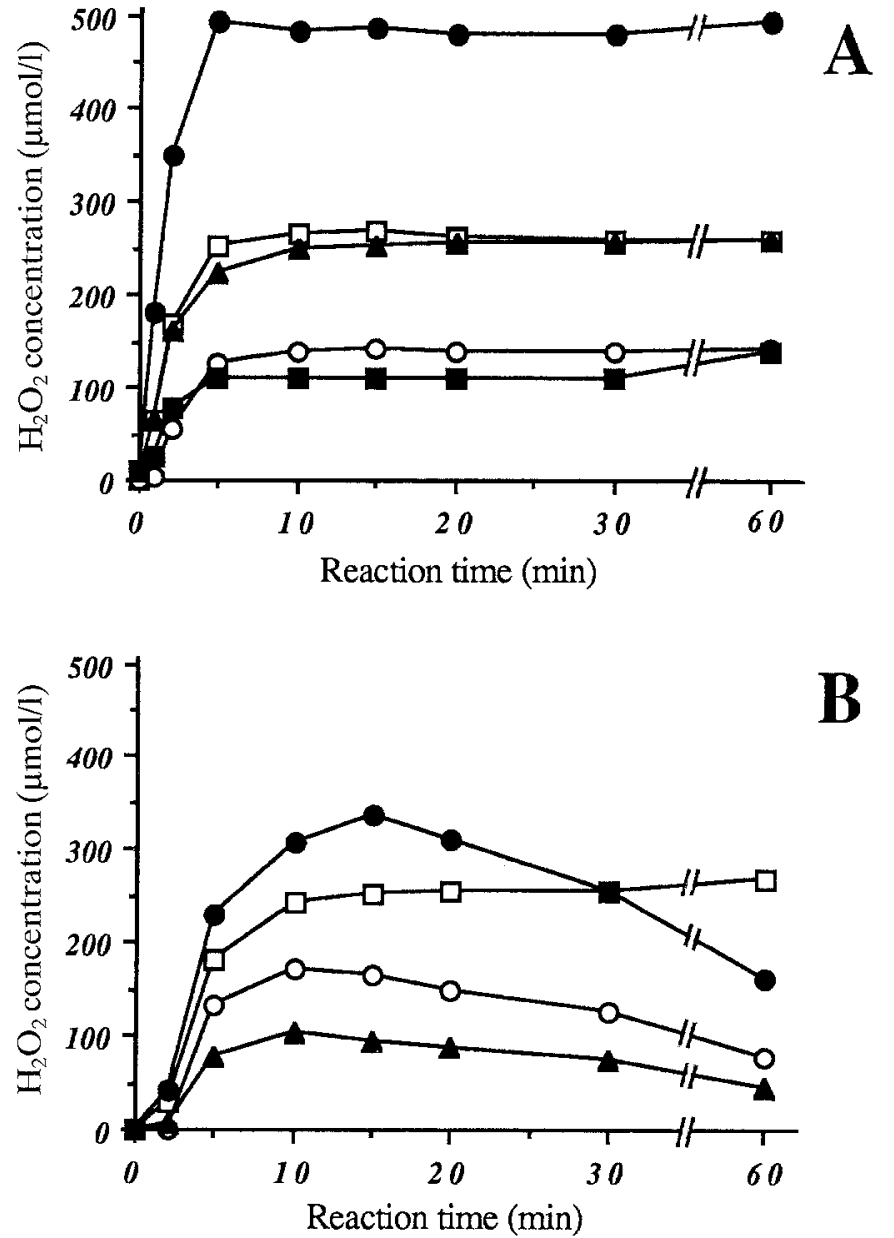

Fig.1. A. Production of hydrogen peroxide $\left(\mathrm{H}_{2} \mathrm{O}_{2}\right)$ when alloxan (A) and cysteine (Cys) react in phosphate-buffered saline at various concentrations with or without desferrioxamine (Des) added. --, $1 \mathrm{mmol} / \mathrm{l} \mathrm{A}+1 \mathrm{mmol} / \mathrm{l} \mathrm{Cys;}-\square-, 500 \mu \mathrm{mol} / \mathrm{l} \mathrm{A}+500 \mu \mathrm{mol} / 1$ Cys; $-\mathbf{A}-, 100 \mu \mathrm{mol} / \mathrm{l}$ Des $+500 \mu \mathrm{mol} / 1 \mathrm{~A}+500 \mu \mathrm{mol} / 1 \mathrm{Cys} ;-\mathrm{O}$ $300 \mu \mathrm{mol} / 1 \mathrm{~A}+300 \mu \mathrm{mol} / 1 \mathrm{Cys} ;-, 100 \mu \mathrm{mol} / 1 \mathrm{~A}+300 \mu \mathrm{mol} / \mathrm{l}$ Cys. The solutions were continuously agitated in order to provide enough oxygen for the reactions. B. Degradation of $\mathrm{H}_{2} \mathrm{O}_{2}$ by $\mathrm{J}-774$ cells during the alloxan/Cys reaction at various concentrations with or without $1.7 \times 10^{5}$ cells, growing as monolayers. -, $1 \mathrm{mmol} / \mathrm{l} \mathrm{A}+1 \mathrm{mmol} / \mathrm{l}$ Cys with cells; $-\square-, \quad 500 \mu \mathrm{mol} / 1$ $\mathrm{A}+500 \mu \mathrm{mol} / \mathrm{l}$ Cys without cells; -O-, $500 \mu \mathrm{mol} / \mathrm{l} \mathrm{A}+500 \mu \mathrm{mol} / 1$ Cys with cells; $-1-, 350 \mu \mathrm{mol} / 1 \mathrm{~A}+350 \mu \mathrm{mol} / 1 \mathrm{l}$ Cys with cells. The reactions took place in $35 \mathrm{~mm}$ plastic Petri cell culture dishes with $2 \mathrm{ml}$ of solution

reactions may occur in the presence of lysosomal iron in reactive form. As a consequence of these two routes, peroxidation may damage not only the plasma membrane but also the lysosomal limiting membranes with leakage of potent hydrolytic enzymes to the cytosol. Situation (ii) dominates when high concentrations of alloxan and cysteine are used $[12,13]$, while mechanism (i) is operative at low alloxan concentrations provided plasma membrane-associated reactive iron is available. The balance between mechanisms (i) and (ii) would theoretically be dependent on the formation of $\mathrm{HO}^{*}$ along the plasma membrane and/or intralysosomally as well as on the efficiency of cellular anti-oxidative defence and repair systems.

\section{Materials and methods}

\section{Chemicals and culture medium}

Nutrient Mixture Ham's F-10 culture medium (F-10), Hepes-buffer, fetal calf serum (FCS), L-glutamine $(200 \mathrm{mmol} / \mathrm{l})$, penicillin-G $(5000 \mathrm{IU} / \mathrm{ml})$ and streptomycin $(5000 \mu \mathrm{mol} / 1)$ were from Gibco (Paisley, Scotland, UK). Alloxan was from Biochemical BDH Ltd. (Poole, Dorset, UK). L-cysteine (Cys), fluorescein diacetate (FDA) and catalase (CAT, EC 1.11.1.6, $4000 \mathrm{IU} / \mathrm{mg}$ ) were purchased from Sigma (St. Louis, Mo. USA). Acridine orange (AO) and ferric chloride (Fe) were from Merck (Darmstadt, FRG). Desferrioxamine (Des) was obtained from Ciba-Geigy (Basel, Switzerland). Superoxide dismutase (SOD, EC 1.15.1.1, $5000 \mathrm{U} / \mathrm{mg}$ ) was from Biochemica (Mannheim, FRG). All other reagents used were obtained from standard sources and of the highest grade available.

\section{Cells and culture conditions}

J-774 cells (an established mouse histiocytic lymphoma cell line) were cultured in $75 \mathrm{~cm}^{2}$ cell culture flasks (Costar, Cambridge, Mass USA) in F-10 supplemented with $10 \% \mathrm{FCS}, 2 \mathrm{mmol} / 1 \mathrm{~L}$-glutamine, $100 \mathrm{IU} / \mathrm{ml}$ penicillin-G and $100 \mu \mathrm{g} / \mathrm{ml}$ streptomycin (complete $\mathrm{F}-10$ medium) in humidified air with $5 \% \mathrm{CO}_{2}$ at $37^{\circ} \mathrm{C}$. Cells were subcultivated once per week (by scraping with a rubber policeman) and plated into either $35 \mathrm{~mm}$ plastic petri cell culture dishes (Costar) with or without $22 \mathrm{~mm}$ glass coverslips $\left(1.7 \times 10^{5} \mathrm{cells} / \mathrm{dish}\right)$ or into multi-well plates (Costar) $\left(8.5 \times 10^{4}\right.$ cells/well). At $120 \mathrm{~min}$ after seeding the cultures were rinsed with F-10 in order to remove nonadhering cells. Fresh complete F-10 medium was added to each dish $(2 \mathrm{ml})$ or to each well $(1 \mathrm{ml})$. The cells were then grown under standard conditions for another $20 \pm 1 \mathrm{~h}$ before start of experiments.

\section{Experimental design}

Cells were always exposed to alloxan/Cys in phosphate-buffered saline (PBS) in order to avoid uncontrolled interference from reducing and oxidative substances which are always present in growth media [12]. Final concentrations of interfering substances, and appropriate exposure times were decided after numerous preliminary experiments on cells cultured and exposed in multiwells. All experiments were performed at $37^{\circ} \mathrm{C}$ and $\mathrm{pH}$ 7.4. Alloxan and Cys were separately dissolved immediately before use in warm PBS to double the final concentrations used in the experiments. Cys in PBS was initially added into each dish $(1 \mathrm{ml})$ or well $(0.5 \mathrm{ml})$ and the reaction was then initiated by the addition of alloxan in PBS ( 1 or $0.5 \mathrm{ml})$. When cells were exposed to interfering substances (protectors or the sensitizer iron) they were preincubated with these substances for the periods of time necessary to get full effect as previously described [12]: (a) $100 \mu \mathrm{mol} / 1 \mathrm{Fe}$ in PBS for $20 \mathrm{~min}$; (b) $50 \mu \mathrm{mol} / 1 \mathrm{Fe}$ in complete F-10 medium for $6 \mathrm{~h}$ followed by a 60 -min rinse in the same medium without iron; (c) $100 \mu \mathrm{mol} / \mathrm{l}$ Des in PBS for $20 \mathrm{~min}$; (d) $100 \mu \mathrm{mol} / 1 \mathrm{Des}+50 \mu \mathrm{g} / \mathrm{ml}$ SOD in PBS for $20 \mathrm{~min}$; (e) $100 \mu \mathrm{mol} / 1 \mathrm{Des}+50 \mu \mathrm{g} / \mathrm{ml} \mathrm{CAT}+50 \mu \mathrm{g} / \mathrm{ml} \mathrm{SOD}$ in PBS for $20 \mathrm{~min}$. After preincubation the cells were exposed to alloxan $(0-2 \mathrm{mmol} / \mathrm{l})$ and Cys $(0-1 \mathrm{mmol} / \mathrm{l})$ in PBS with or without combinations of Des, CAT and SOD (but not Fe) present in the same concentrations as during preincubation in PBS. Viability and permeability of plasma and lysosomal membranes were then evaluated as described below.

\section{Hydrogen peroxide production and degradation}

Hydrogen peroxide $\left(\mathrm{H}_{2} \mathrm{O}_{2}\right)$ production during the alloxan/Cys reaction and its degradation by J-774 cells were measured in $2 \mathrm{ml}$ PBS with or without $1.7 \times 10^{5}$ cells at different alloxan and Cys concentra- 
tions (alloxan, $100-1000 \mu \mathrm{mol} / \mathrm{l}$; Cys, $100-1000 \mu \mathrm{mol} / \mathrm{l}$ ) with or without Des $(100 \mu \mathrm{mol} / \mathrm{l})$ present. $\mathrm{H}_{2} \mathrm{O}_{2}$ was assayed by a modified $\mathrm{p}$-hydroxyphenylacetic acid (PHPA)/horseradish peroxidase (HRP) technique $[30,31]$. Intensities of fluorescence $(315 / 410 \mathrm{~nm})$ were read in a RF-540 spectrofluorophotometer connected to a DR-3 Data recorder (Shimadzu, Kyoto Japan).

\section{Evaluation of cell viability}

Cell viability after exposure to alloxan, Cys and other substances was estimated by using the trypan blue dye exclusion test [32,33]. Stained and unstained cells were counted in ten randomly chosen areas of each culture after exposure for 5 min to trypan blue $(0.05 \%$ in PBS, $\mathrm{pH} 7.4$, at $20^{\circ} \mathrm{C}$ ). Usually about 800 cells were scored from each sample.

\section{Evaluation of plasma membrane permeability}

After exposure to the indicated concentrations of alloxan/Cys (see experimental design) plasma membrane permeability was assessed by using a modified [12] FDA $\left(2.5 \mu \mathrm{g} / \mathrm{ml}\right.$ in PBS at $20^{\circ} \mathrm{C}$ for $\left.3 \mathrm{~min}\right)$ vital staining technique $[34,35]$. The fluorescence of individual FDA-stained cells grown on glass coverslips was measured with a MPV III Leitz static cytofluorometer (Wetzlar, FRG) connected to a small ABC 800 computer system [36] as described previously [12, 13]. The intensities of FDA-induced green fluorescence were recorded from 100 randomly chosen cells in each sample.

Estimation of cell death or damage by the trypan blue dye exclusion test is an insensitive technique since it only discriminates between extensively damaged or dead cells and less severely damaged ones, some of which may later die. Other systems to evaluate cell viability, such as estimation of released lactic acid dehydrogenase or ${ }^{51} \mathrm{Cr}$, do not offer increased sensitivity. The modified [12] FDA technique with fluorometric evaluation of retained fluorescein-induced fluorescence using computerized microfluorometry for evaluation of plasma membrane stability is, however, very sensitive and allows discrimination of different degrees of plasma membrane damage.

\section{Evaluation of lysosomal membrane stability}

Cells cultured on glass coverslips were initially stained with $2 \mathrm{ml} \mathrm{AO}$ solution $\left(5 \mu \mathrm{g} / \mathrm{ml}\right.$ in complete $\mathrm{F}-10$ medium) at $37^{\circ} \mathrm{C}$ for $15 \mathrm{~min}[37$, 38]. Following a quick rinse with warm $\left(37^{\circ} \mathrm{C}\right) \mathrm{PBS}$, the AO-loaded cells were then exposed to alloxan and Cys and occasional additives, as described. The intensities of AO-induced red and green fluorescences were simultaneously recorded individually from 100 cells on each coverslip by the MPV III static microfluorometer, using a double detector system for red and green light (barrier filters 630 and $546 \mathrm{~nm}$, respectively).

\section{Cytochemical demonstration of iron}

A modified sulphide-silver (autometallography) technique [39-42] was utilized to demonstrate the location of iron. After $20 \mathrm{~h}$ in culture, cells were exposed to $50 \mu \mathrm{mol} / \mathrm{Fe}$ in complete $\mathrm{F}-10$ medium for $6 \mathrm{~h}$ followed by $1 \mathrm{~h}$ in the same medium without iron, at standard culture conditions. Other cells were exposed to $100 \mu \mathrm{mol} / \mathrm{l} \mathrm{Fe}$ for $20 \mathrm{~min}$ in PBS. The cells were then briefly rinsed in PBS before fixation with $2 \%$ glutaraldehyde in $0.1 \mathrm{~mol} / \mathrm{l} \mathrm{Na}$-cacodylate with $0.1 \mathrm{~mol} / \mathrm{l}$ sucrose for $2 \mathrm{~h}$ at $22^{\circ} \mathrm{C}$. Following short rinses $(\times 5)$ in double distilled water, the cells were sulphidated in $1 \%$ ammonium sulphide (to convert $\mathrm{Fe}$ to $\mathrm{FeS}$ ) in $70 \%$ ethanol for $15 \mathrm{~min}$ [41]. The samples were then carefully rinsed with distilled water for $10 \mathrm{~min}$ and developed in a physical, colloid protected, photographic developer [42] containing Ag-lactate $(0.11 \mathrm{~g}$ in $15 \mathrm{ml}$ distilled water), hydroquinone $(0.85 \mathrm{~g}$ in $15 \mathrm{ml}$ distilled water), $60 \mathrm{ml} 25 \%$ gum arabic and $10 \mathrm{ml} \mathrm{Na-citrate} \mathrm{buffer}(\mathrm{pH} 3.8)$ for $10 \mathrm{~min}$ to precipitate $\mathrm{Ag}$ as a shell around the FeS nuclei. After dehydration in a gradient series of ethanol the cells were mounted in Canada balsam [40].

\section{Statistical analysis}

All experiments were performed in triplicate as a minimum. Data are presented as mean $\pm S E M$. Based on findings that values were normally distributed, Student's $t$-test was used to evaluate differences between groups and $p$-values less than $5 \%$ were considered to be statistically significant.

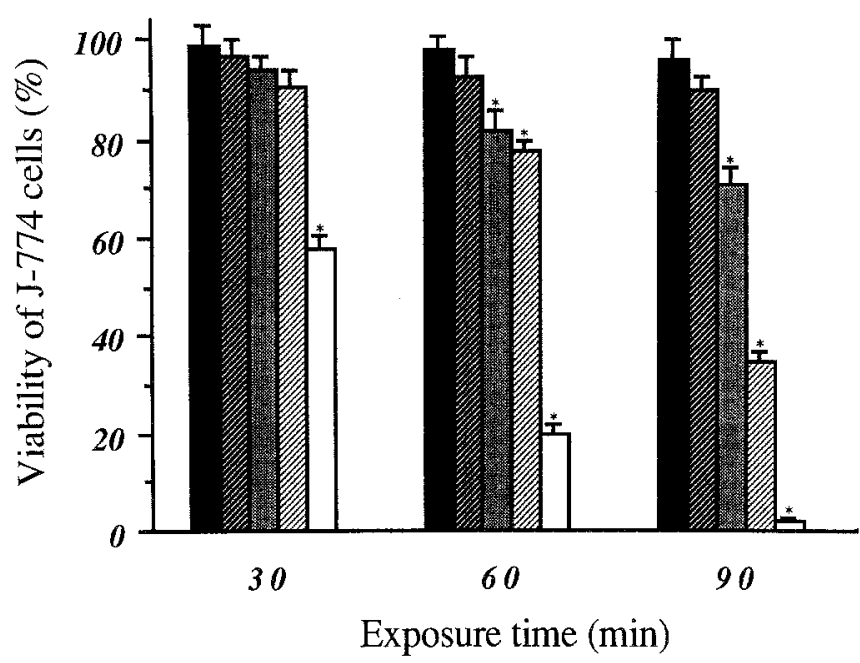

Fig. 2. Trypan blue dye exclusion by J-774 cells after being exposed to various concentrations of alloxan (A) and cysteine (Cys) in phosphate-buffered saline (PBS) for indicated periods of time. $1, P B S$; , $250 \mu \mathrm{mol} / \mathrm{A} \mathrm{A}+250 \mu \mathrm{mol} / 1 \mathrm{Cys} ;$ 燯, $350 \mu \mathrm{mol} / 1 \mathrm{~A}+350 \mu \mathrm{mol} / 1$ Cys; 浱, $500 \mu \mathrm{mol} / \mathrm{l} \mathrm{A}+500 \mu \mathrm{mol} / \mathrm{l} \mathrm{Cys} ; \square, 2 \mathrm{mmol} / \mathrm{l} \mathrm{A}+1 \mathrm{mmol} / 1$ Cys. " $p<0.05$ vs controls in PBS

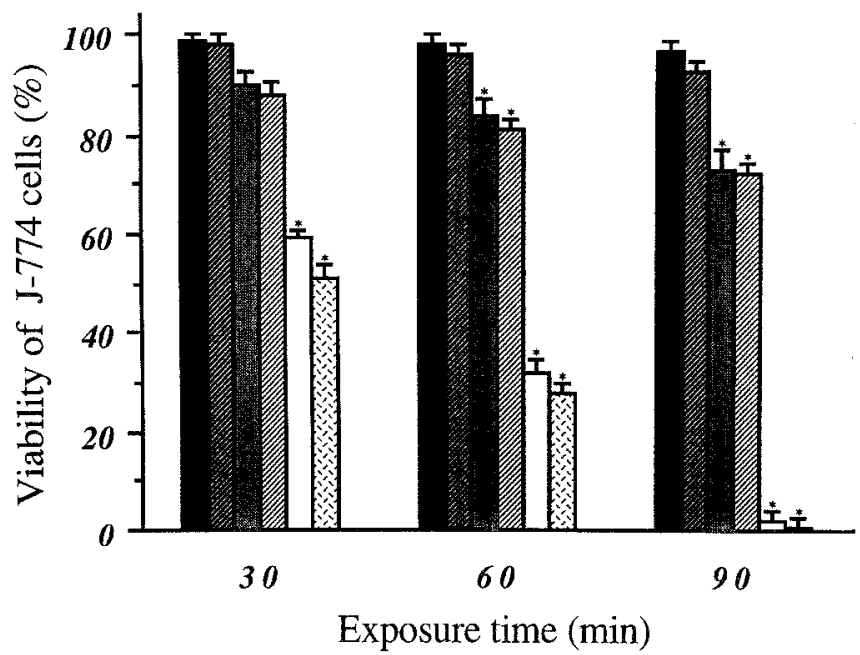

Fig. 3. Trypan blue dye exclusion by J-774 cells after being exposed to high concentrations of alloxan (A) and cysteine (Cys) in phosphate-buffered saline (PBS) for indicated periods of time with or without preexposure (as explained in the Materials and methods section) to catalase (CAT), superoxide dismutase (SOD), desferrioxamine (Des) or $\mathrm{FeCl}_{3}(\mathrm{Fe})$. 1 , PBS; 猖, $100 \mu \mathrm{mol} / 1 \mathrm{Des}+50 \mu \mathrm{g} / \mathrm{ml}$ $\mathrm{CAT}+50 \mu \mathrm{g} / \mathrm{ml} \mathrm{SOD}+2 \mathrm{mmol} / \mathrm{l} \mathrm{A}+1 \mathrm{mmol} / \mathrm{l} \mathrm{Cys} ;$ r $100 \mu \mathrm{mol} / \mathrm{h}$ $\mathrm{Des}+50 \mu \mathrm{g} / \mathrm{ml} \mathrm{SOD}+2 \mathrm{mmol} / \mathrm{l} \mathrm{A}+1 \mathrm{mmol} / \mathrm{l} \mathrm{Cys}$; $100 \mu \mathrm{mol} / \mathrm{l}$ $\mathrm{Des}+2 \mathrm{mmol} / \mathrm{l} \mathrm{A}+1 \mathrm{mmol} / \mathrm{l} \mathrm{Cys} ; \square, 2 \mathrm{mmol} / \mathrm{l} \mathrm{A}+1 \mathrm{mmol} / \mathrm{Cys}$; , $50 \mu \mathrm{mol} / \mathrm{l} \mathrm{Fe}$ for $6 \mathrm{~h}+2 \mathrm{mmol} / \mathrm{l} \mathrm{A}+1 \mathrm{mmol} / \mathrm{l} \mathrm{Cys.}{ }^{*} p<0.05 \mathrm{vs}$ controls in PBS 


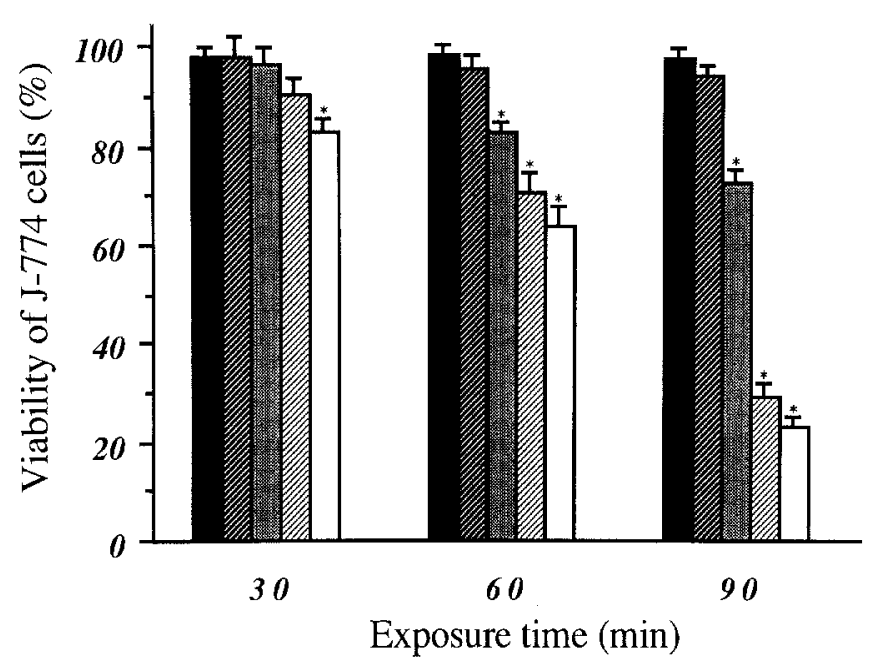

Fig.4. Trypan blue dye exclusion by J-774 cells after being exposed to low concentrations of alloxan (A) and cysteine (Cys) in phosphate-buffered saline (PBS) for indicated periods of time with or without preexposure to desferrioxamine (Des) or $\mathrm{FeCl}_{3}(\mathrm{Fe})$. $\square$ PBS; $100 \mu \mathrm{mol} / \mathrm{l}$ Des $+350 \mu \mathrm{mol} / \mathrm{l} \mathrm{A}+350 \mu \mathrm{mol} / \mathrm{l}$ Cys; $350 \mu \mathrm{mol} / 1 \quad \mathrm{~A}+350 \mu \mathrm{mol} / 1 \quad \mathrm{Cys}$; $100 \mu \mathrm{mol} / 1 \mathrm{Fe}$ for $20 \mathrm{~min}+350 \mu \mathrm{mol} / 1 \mathrm{~A}+350 \mu \mathrm{mol} / \mathrm{l}$ Cys; $\square, 50 \mu \mathrm{mol} / 1 \mathrm{Fe}$ for $6 \mathrm{~h}+350 \mu \mathrm{mol} / \mathrm{l} \mathrm{A}+350 \mu \mathrm{mol} / \mathrm{l} \mathrm{Cys}$. ${ }^{*} p<0.05 \mathrm{vs}$ controls in PBS

\section{Results}

\section{Hydrogen peroxide production and degradation}

The $\mathrm{H}_{2} \mathrm{O}_{2}$ production during the reactions between alloxan and Cys at various concentrations with or without Des was followed for $60 \mathrm{~min}$. The final amount of $\mathrm{H}_{2} \mathrm{O}_{2}$ formed was Cys-dependent. Des did not influence $\mathrm{H}_{2} \mathrm{O}_{2}$ production (Fig.1 A).

The $\mathrm{H}_{2} \mathrm{O}_{2}$ produced was partly degraded by the cells. Cells exposed to alloxan and Cys at low concentration ( 350 and $350 \mu \mathrm{mol} / 1$ ) were thus only briefly exposed to $\mathrm{H}_{2} \mathrm{O}_{2}$ at a concentration greater than $100 \mu \mathrm{mol} / \mathrm{l}$ (Fig. $1 \mathrm{~B}$ ).

\section{Evaluation of cell viability}

In order to obtain preliminary information about alloxan/Cys cytotoxicity for subsequent and more detailed studies, cells grown in multiwell plates were initially exposed to different concentrations of alloxan $(0-2 \mathrm{mmol} / \mathrm{l})$ and Cys $(0-1 \mathrm{mmol} / \mathrm{l})$ in PBS (without additives or any type of preincubation) for periods up to $90 \mathrm{~min}$. Viability was thereafter evaluated by the trypan blue dye exclusion test. As shown in Figure 2, exposure to alloxan/Cys of 2 and $1 \mathrm{mmol} / \mathrm{l}$ caused more than $95 \%$ cell death within $90 \mathrm{~min}$, while exposure to alloxan/Cys of 350 and $350 \mu \mathrm{mol} / \mathrm{l}$ or 250 and $250 \mu \mathrm{mol} / / \mathrm{resulted}$ in approximately $30 \%$ or less than $5 \%$ cell death, respectively.

After preincubation with the protectors Des; Des and SOD; or Des, SOD and CAT (20 min in PBS), respectively, cells were exposed to alloxan/Cys at high concentrations ( 2 and $1 \mathrm{mmol} / \mathrm{l}$ ), along with the above-mentioned protectors present, for up to $90 \mathrm{~min}$. Cell damage was found to be either, partially or almost completely prevented (Fig.3).

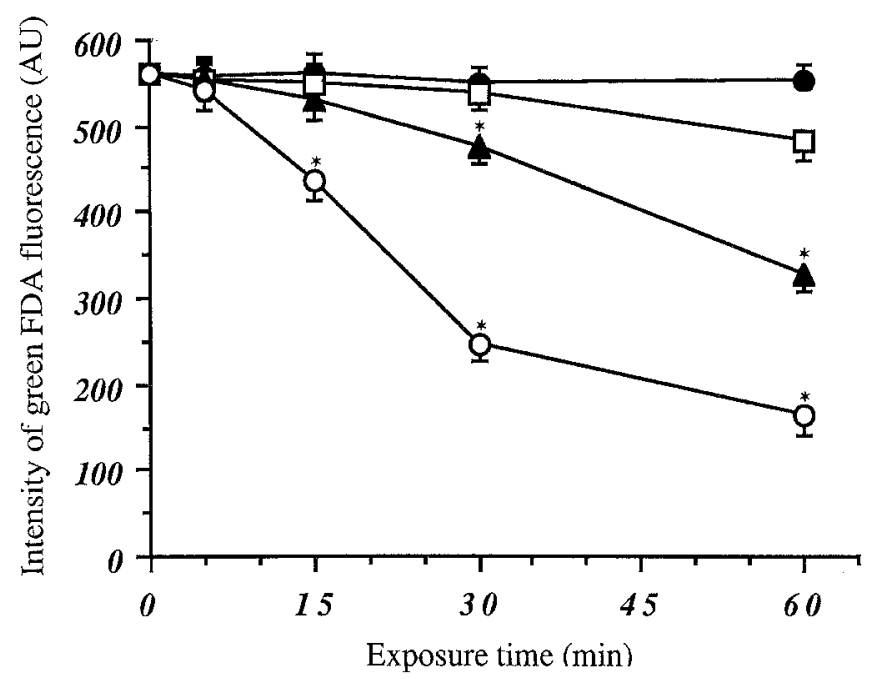

Fig.5. Fluorescein diacetate (FDA)-induced fluorescence of J-774 cells. The FDA staining was done after an initial exposure to alloxan (A) and cysteine (Cys) at low concentrations $(350 \mu \mathrm{mol} / 1+350 \mu \mathrm{mol} / 1)$ in phosphate-buffered saline (PBS) for indicated periods of time with or without desferrioxamine (Des) or $\mathrm{FeCl}_{3}(\mathrm{Fe})$. - - , PBS; $-\square-,, 100 \mu \mathrm{mol} / \mathrm{l}$ Des $+350 \mu \mathrm{mol} / 1 \mathrm{~A}+350 \mu \mathrm{mol} / 1 \mathrm{Cys} ;-\Lambda-, 350 \mu \mathrm{mol} / 1 \mathrm{~A}+350 \mu \mathrm{mol} / \mathrm{l}$ Cys; $-0-100 \mu \mathrm{mol} / 1 \mathrm{Fe}$ for $20 \mathrm{~min}+350 \mu \mathrm{mol} / \mathrm{l} \mathrm{A}+350 \mathrm{mmol} / \mathrm{l}$ Cys. ${ }^{*} p<0.05$ vs controls in PBS

Cells initially allowed to endocytose iron for $6 \mathrm{~h}$ (enhancing their lysosomal content of catalytically active iron) showed somewhat increased sensitivity (Fig. 3).

When cells were exposed to alloxan/Cys at low concentrations $(350$ and $350 \mu \mathrm{mol} / \mathrm{l})$ cell injury was completely prevented by $100 \mu \mathrm{mol} / \mathrm{l}$ Des present extracellularly during exposure (Fig. 4). In contrast, $\mathrm{Fe}$-exposed cells (either $100 \mu \mathrm{mol} / \mathrm{l}$ for $20 \mathrm{~min}$ in PBS or $50 \mu \mathrm{mol} / 1$ for $6 \mathrm{~h}$ in complete F-10 medium) were much more sensitive than cells exposed to alloxan/Cys alone (Fig.4). The results of viability estimations were about the same whether performed immediately at the end of the 30-90 min exposure period to alloxan/Cys in PBS or $12 \mathrm{~h}$ later after cells were returned to ordinary culture conditions (Table 1).

\section{Evaluation of plasma membrane permeability}

As shown in Figure 5, cells exposed to alloxan/Cys at low concentrations (350 and $350 \mu \mathrm{mol} / \mathrm{l}$ ) showed a rapid, and rather pronounced, decline in green FDA-induced fluorescence over a 60-min period. Iron-exposed cells $(100 \mu \mathrm{mol} / \mathrm{l}$ for $20 \mathrm{~min})$ showed a markedly more evident decline of FDA retention under the same conditions, while cells pre-exposed to Des, and then exposed to alloxan and Cys in the presence of Des, behaved almost as control cells exposed to PBS only.

\section{Evaluation of lysosomal membrane stability}

AO-exposed control cells showed a granular, bright red, cytoplasmic fluorescence (lysosomes) in combination with weak green nuclear fluorescence when excited with blue light (Fig. 6A). If such AO-loaded cells were exposed 
Table 1. Cell viability $12 \mathrm{~h}$ after exposure to alloxan and cysteine

\begin{tabular}{lllll}
\hline $\begin{array}{l}\text { Exposure } \\
\text { time (min) }\end{array}$ & $\begin{array}{l}\text { Alloxan }+ \\
\text { Cysteine } \\
(\mu \mathrm{mol} / \mathrm{l})\end{array}$ & \multicolumn{3}{c}{ Additives during exposure } \\
\cline { 2 - 5 } & $50+50$ & 100 & $\mathrm{Fe}$ & Des \\
\hline 30 & $100+100$ & $99 \pm 1$ & $99 \pm 1$ & 100 \\
& $200+200$ & $98 \pm 2$ & $93 \pm 3$ & $99 \pm 1$ \\
& $350+350$ & $94 \pm 6$ & $81 \pm 5^{\mathrm{a}}$ & $98 \pm 2$ \\
& $50+50$ & 100 & 100 & 100 \\
60 & $100+100$ & $99 \pm 1$ & $99 \pm 1$ & 100 \\
& $200+200$ & $98 \pm 1$ & $93 \pm 4$ & $98 \pm 2$ \\
& $350+350$ & $75 \pm 7^{\mathrm{a}}$ & $56 \pm 8^{\mathrm{a}}$ & $95 \pm 3$ \\
& $50+50$ & 100 & 100 & 100 \\
90 & $100+100$ & $97 \pm 1$ & $96 \pm 1$ & 100 \\
& $200+200$ & $94 \pm 3$ & $86 \pm 3^{\mathrm{a}}$ & $98 \pm 1$ \\
& $350+350$ & $63 \pm 8^{\mathrm{a}}$ & $22 \pm 6^{\mathrm{a}}$ & $92 \pm 5$ \\
\hline
\end{tabular}

J-774 cells were exposed to alloxan and cysteine for 30,60 and $90 \mathrm{~min}$ at various concentrations in phosphate-buffered saline (PBS) with or without $100 \mu \mathrm{mol} / 1 \mathrm{FeCl}_{3}(\mathrm{Fe})$ or $100 \mu \mathrm{mol} / \mathrm{l}$ desferrioxamine (Des), then rinsed in PBS and brought back to complete F-10 medium under standard culture conditions for another $12 \mathrm{~h}$. Viability was then evaluated by the trypan blue dye exclusion test. Values are expressed as \% live (unstained) cells \pm SEM. ${ }^{a} p<0.05$ vs controls in PBS

to high concentrations of alloxan/Cys ( 2 and $1 \mathrm{mmol} / \mathrm{l}$ ), the original AO-fluorescence pattern shifted within $5 \mathrm{~min}$ to a diffuse, green-yellow, cytoplasmic fluorescence with only occasional red granules. Such cells also showed evident blebbing within the same period of time (Fig.6B). On the other hand, AO-loaded cells exposed to low concentrations of alloxan/Cys ( 350 and $350 \mu \mathrm{mol} / 1)$ retained most of their granular red cytoplasmic fluorescence and showed only slightly increased, green nuclear and cytosolic fluorescence, even after exposure times as long as $30 \mathrm{~min}$ (Fig. 6C).

The photo-multiplying system of the MPV III microfluorometer is more sensitive to green than to red photons making studies of alterations of red fluorescence less sensitive than that of green (Fig.7A). Values for red and green fluorescence after exposure to high (2 and $1 \mathrm{mmol} / \mathrm{l})$ and low ( 350 and $350 \mu \mathrm{mol} / \mathrm{l})$ concentrations of alloxan and Cys in PBS without addition of protectors or iron (sensitizer) are shown in Figures $7 \mathrm{~B}$ and $\mathrm{C}$.

\section{Distribution of intracellular iron}

Control cells showed only occasional granular silver precipitates after a short $(10 \mathrm{~min})$ development period, indicating the normal lysosomal content of heavy metals (Fig. $8 \mathrm{~A})$. Fe-loaded cells $\left(50 \mu \mathrm{mol} / 1 \mathrm{FeCl}_{3}\right.$ in complete $\mathrm{F}$ 10 medium for $6 \mathrm{~h}$ followed by 1 -h rinse in the same medium without iron) showed distinct granular silver precipitation after the 10 -min period of development indicating a much increased concentration of iron within the secondary lysosomes (Fig. 8B). Cells exposed to $100 \mu \mathrm{mol} / \mathrm{l}$ $\mathrm{FeCl}_{3}$ in $\mathrm{PBS}$ for 20 min showed black silver precipitates along the plasma membrane, indicating iron adsorption to the plasma membrane, but not more lysosomal silver precipitates than in the control cells (Fig. 8C).
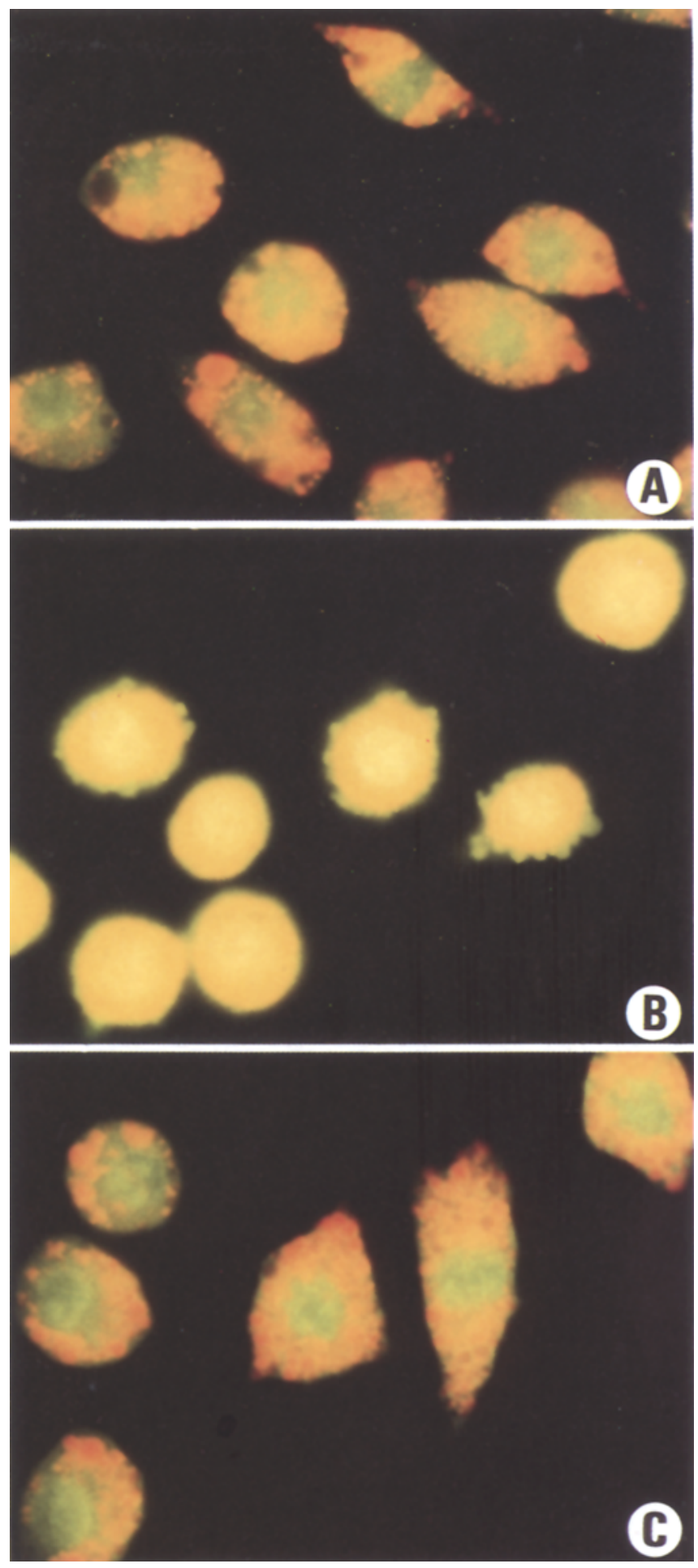

Fig.6 A-C. Alterations of acridine orange (AO)-induced fluorescence with respect to pattern and colour after ensuing exposure of AO-loaded $\mathrm{J}-774$ cells to high or low concentrations of alloxan $(2 \mathrm{mmol} / 1$ or $350 \mu \mathrm{mol} / \mathrm{l})$ and cysteine $(1 \mathrm{mmol} / 1$ or $350 \mu \mathrm{mol} / \mathrm{l})$ in phosphate-buffered saline (PBS). A Control cells exposed to only PBS show bright red granular, cytosolic fluorescence and weak green nuclear fluorescence. B The AO-fluorescence shifted from red granular to diffuse yellowgreen cytoplasmic after exposure for 5 min to the high concentrations of alloxan and Cys. This colour shift was accompanied by obvious cell blebbing. C Cells exposed to the low concentrations of alloxan and Cys retained a similar $\mathrm{AO}$-distribution pattern as observed in control cells, even after 30 min exposure. Magnification $(\mathbf{A}-\mathbf{C}) \times 1100$ 

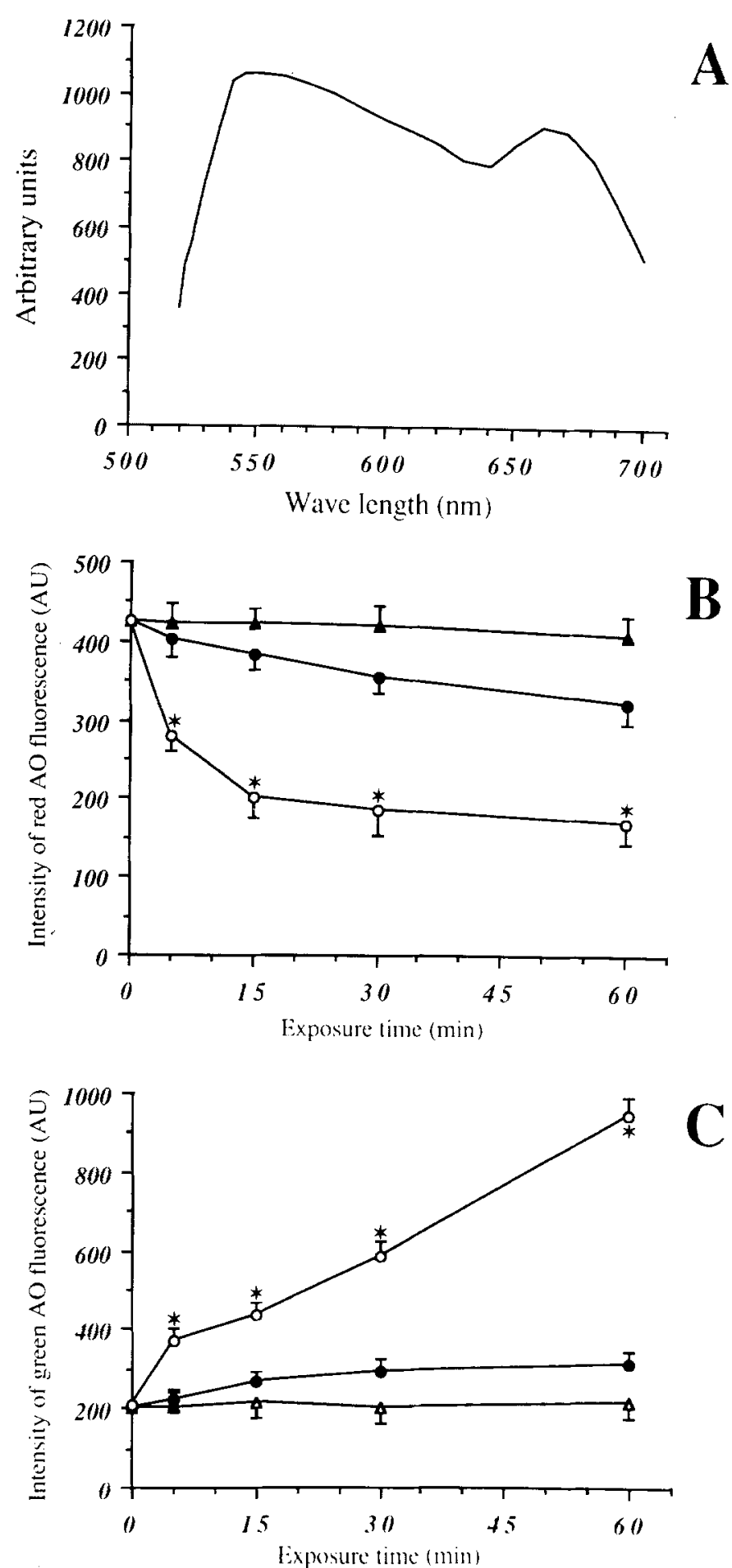

Fig. 7A-C. As shown in A the sensitivity of the photo-multiplying system of the MPV III microfluorometer system varies for photons of different wavelengths. Acridine orange (AO)-induced fluorescence in J-774 cells after exposure to high and low concentrations of alloxan (A) and cysteine (Cys) in phosphate-buffered saline (PBS) for indicated periods of time showed differing alterations of red (B -A - PBS; - $-350 \mu \mathrm{mol} / 1 \mathrm{~A}+350 \mu \mathrm{mol} / 1 \mathrm{Cys} ;-0-, 2 \mathrm{mmol} / 1$ $\mathrm{A}+1 \mathrm{mmol} / \mathrm{l} \mathbf{C y s})$ and green fluorescence $(\mathbf{C}-\triangle-, \mathrm{PBS} ;-\mathbf{-}$, $350 \mu \mathrm{mol} / 1 \mathrm{~A}+350 \mu \mathrm{mol} / \mathrm{l} \mathrm{Cys} ;-\mathrm{O}-, 2 \mathrm{mmol} / \mathrm{l} \mathrm{A}+1 \mathrm{mmol} / \mathrm{l} \mathrm{Cys})$. " $p<0.05$ vs controls in PBS

\section{Discussion}

In the present study an established macrophage-like cell line ( $\mathrm{J}-774$ ) was utilized as an experimental model system to further investigate the mechanisms behind short-term alloxan cytotoxicity. We have previously showed this toxicity to be caused by an extracellular production of reactive oxygen metabolites formed during reactions between alloxan and various reducing agents $[12,13]$. We have so far used the lysosome-rich J-774 cells, having pronounced exocytotic capacity (reversed endocytosis), as a model system. Since we feel that interference with the stability of secondary lysosomes and a high capacity to exocytose might be involved in alloxan cytotoxicity, we preferred to initially use these easily manipulated cells. The obtained knowledge will later be explored in experiments (in progress) on purified mouse beta cells and cultured, established insulinoma cells which, of course, might differ with respect to alloxan interference.

Alloxan and reducing agents, such as cysteine, glutathione or ascorbic acid, interact to form $\mathrm{O}_{2}{ }^{-}$and $\mathrm{H}_{2} \mathrm{O}_{2}$ $[12,15,25]$. Depending on the concentrations of alloxan and reducing substances $\mathrm{H}_{2} \mathrm{O}_{2}$ will form in different amounts.

Cells possess anti-oxidant protection systems, including glutathione-GSH and catalase, with a rather pronounced $\mathrm{H}_{2} \mathrm{O}_{2}$ degrading capacity [43]. The toxic effects of $\mathrm{H}_{2} \mathrm{O}_{2}$ depend not only on the total amount of $\mathrm{H}_{2} \mathrm{O}_{2}$ produced, but also on the period of time during which the $\mathrm{H}_{2} \mathrm{O}_{2}$ is produced. $\mathrm{H}_{2} \mathrm{O}_{2}$, due to its degradation, may never reach very high into alloxan concentrations when produced comparatively slowly.

$\mathrm{O}_{2}{ }^{-}$dismutates spontaneously, or through SOD activity, to $\mathrm{H}_{2} \mathrm{O}_{2}$ and $\mathrm{O}_{2}$ (reaction 1 ). $\mathrm{HO}^{\circ}$ will be formed from $\mathrm{H}_{2} \mathrm{O}_{2}$ through the iron-dependent Fenton reaction [27] which may be superoxide-driven, or due to the reducing capacity of dialuric acid $\left(\mathrm{AH}_{2}\right)$ which will be in turn oxidized back to alloxan through intermediate formation of alloxan radicals $\left(\mathrm{AH}^{*}\right)$ (reactions 2-4 and Fig. 9) [15]. Both $\mathrm{O}_{2}{ }^{-1}$ and $\mathrm{AH}_{2}$ will reduce ferric iron to its ferrous form.

$\mathrm{O}_{2}^{\cdot-}+\mathrm{O}_{2}^{\cdot-}+2 \mathrm{H}^{+} \rightarrow \mathrm{H}_{2} \mathrm{O}_{2}+\mathrm{O}_{2}$

$\mathrm{H}_{2} \mathrm{O}_{2}+\mathrm{Fe}^{2+} \rightarrow \mathrm{Fe}^{3+}+\mathrm{HO}^{\circ}+\mathrm{OH}^{-}$

$\mathrm{O}_{2}^{\cdot-}+\mathrm{Fe}^{3+} \rightarrow \mathrm{O}_{2}+\mathrm{Fe}^{2+}$

$\mathrm{AH}_{2}+\mathrm{Fe}^{3+} \rightarrow \mathrm{Fe}^{2+}+\mathrm{AH}^{*}+\mathrm{H}^{+}$

Neither $\mathrm{O}_{2}{ }^{--}$nor $\mathrm{H}_{2} \mathrm{O}_{2}$ are considered particularly toxic [44-46]. If reactive iron is available, however, the iron will contribute to formation of the much more aggressive $\mathrm{HO}^{\circ}$. Trace amounts of ferric iron together with $\mathrm{O}_{2}{ }^{-}$and $\mathrm{H}_{2} \mathrm{O}_{2}$ will thus induce formation of $\mathrm{HO}^{*}$ in close proximity (site-specifically) to the iron atoms [25, $27,44,45$ ], initiating peroxidative chain-reactions causing severe cellular damage if it occurs at cellular membranes.

It should be pointed out that trace amount of iron is a common contamination in buffers and is always present in culture media, thus making cultured cells living in an artificial milieu very different from that of cells in situ with respect to iron exposure. In situ cells are usually never exposed to iron in reactive form since unsaturated transfer- 
rin and other iron-chelating systems are present. Iron contamination of PBS or culture media may explain why Des is required to prevent $\mathrm{HO}^{*}$ formation in in vitro systems, even when no iron has been added [12].

As previously published [12-14], and demonstrated again in the present study, cells exposed to high concentrations of alloxan $(2 \mathrm{mmol} / \mathrm{l})$ and the reducing agent Cys $(1 \mathrm{mmol} / \mathrm{l})$ will succumb mainly due to the toxic effects of large amounts of $\mathrm{H}_{2} \mathrm{O}_{2}$ after its diffusion into the cells. The poor protection, under these conditions, by Des alone or Des and SOD showed that neither $\mathrm{HO}^{\bullet}$ nor $\mathrm{O}_{2}{ }^{-}$, produced extracellularly, then contribute much to the toxicity. Being a non-polar molecule, $\mathrm{H}_{2} \mathrm{O}_{2}$ will readily diffuse into cells and rapidly equilibrate within all cellular compartments. Some lysosomal iron is always present due to autophagocytotic degradation of iron-containing metalloproteins $[41,47,48]$, thus $\mathrm{H}_{2} \mathrm{O}_{2}$ may initiate Fenton reactions intralysosomally. The formation of $\mathrm{HO}^{*}$ would cause lysosomal membrane damage with disappearance of its proton gradient, as can be demonstrated by the red to green shift of the AO-induced fluorescence. The cells started blebbing within a few min suggesting that hydrolytic lysosomal enzymes are released to the cytosol in analogy with findings in other systems in which lysosomes were disrupted by photo-oxidation [49] or the direct exposure to $\mathrm{H}_{2} \mathrm{O}_{2}$ [48]. Under conditions of high-concentration-exposure to alloxan/Cys the addition of CAT, SOD and Des to the incubating medium resulted in full protection indicating that $\mathrm{O}_{2}{ }^{--}$and $\mathrm{H}_{2} \mathrm{O}_{2}$ are only formed extracellularly and implying that alloxan cytotoxicity does, at least in this model system, not require its cellular uptake.

Alloxan/Cys at low concentrations seem to exert toxicity due to site-specific $\mathrm{HO}^{*}$ production in relation to the plasma membrane. The addition of the specific iron-chelater Des, blocking iron-catalysed Fenton reactions, to the incubating medium almost completely prevented cell death, confirming that $\mathrm{H}_{2} \mathrm{O}_{2}$ produced at low concentrations under relatively long periods of time does not break through the cellular anti-oxidative defence systems and does not reach the secondary lysosomes to any major degree (no substantial AO-fluorescence shift from red to green). Under these conditions of $\mathrm{O}_{2}{ }^{--}$and $\mathrm{H}_{2} \mathrm{O}_{2}$ production in low amounts, however, plasma membrane associated iron would be reduced from $\mathrm{Fe}^{3+}$-complexes to $\mathrm{Fe}^{2+}$ complexes by the produced $\mathrm{O}_{2}{ }^{\circ}$. Reduced iron, in catalytically active form, interacts with $\mathrm{H}_{2} \mathrm{O}_{2}$ to produce $\mathrm{HO}^{\circ}$ (Fenton reaction) that abstracts hydrogen from plasma membrane phospholipids initiating chain reactions leading to peroxidation, fragmentation and eventually cellular death.

In the present model system we have shown the enhancement of alloxan cytotoxicity following either a short $\left(20 \mathrm{~min}\right.$ ) incubation of the cells with $100 \mu \mathrm{mol} / \mathrm{l} \mathrm{FeCl} \mathrm{Fe}_{3} \mathrm{re}$ sulting in some iron-adsorption by plasma membranes, or after allowing the cells to enrich $\left(50 \mu \mathrm{mol} / 1 \mathrm{FeCl}_{3}\right.$ for $\left.6 \mathrm{~h}\right)$ their secondary lysosomes with endocytosed iron before being exposed to alloxan and reducing agents. These findings demonstrate the importance of iron-catalysed $\mathrm{HO}^{*}$ formation. In the latter case (iron-rich lysosomes) reversed endocytosis, or exocytosis, would result in the

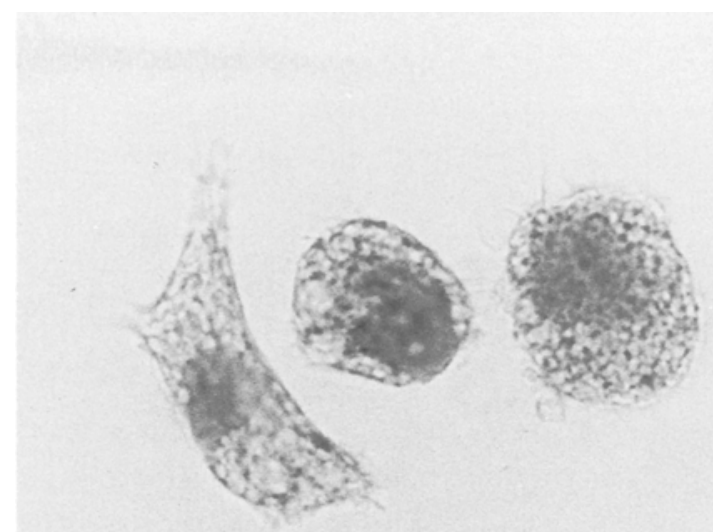

A

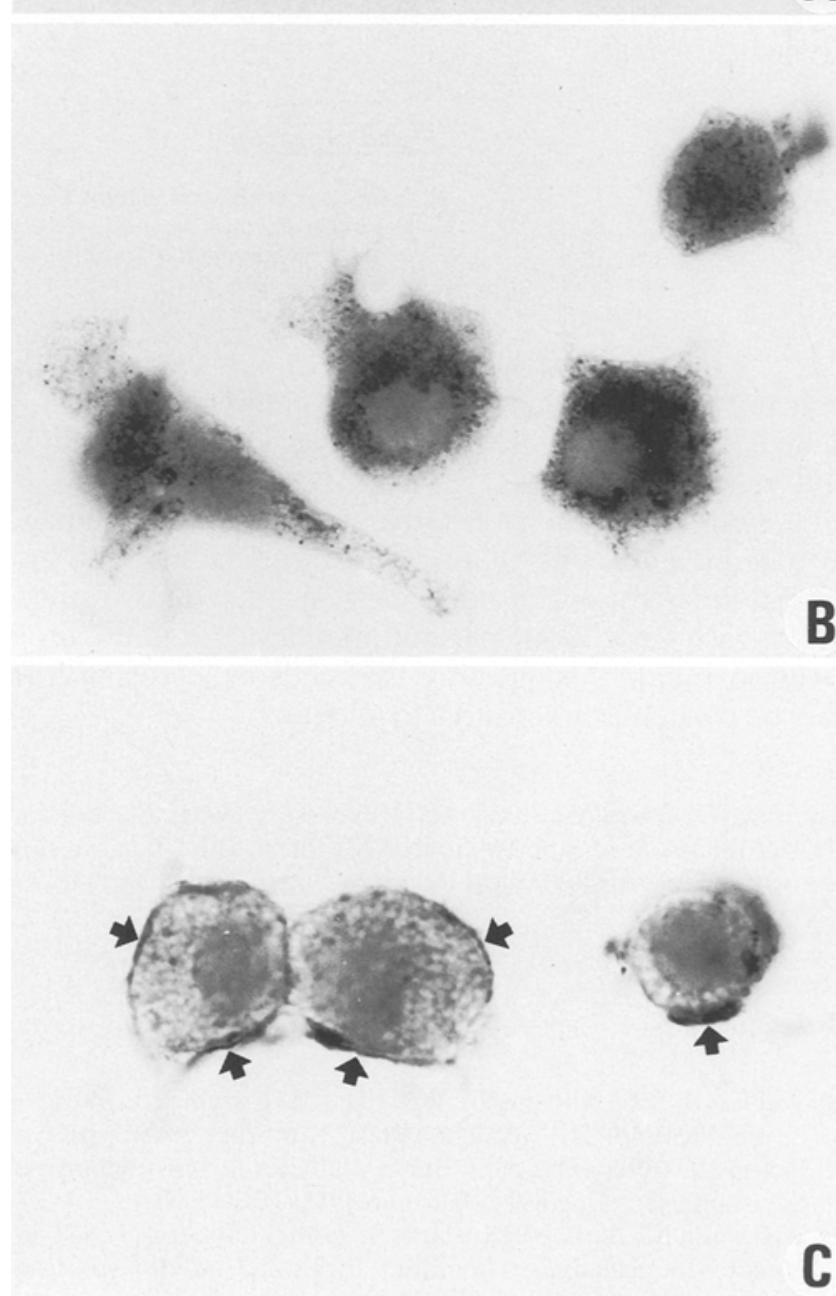

Fig.8A-C. Cytochemical demonstration (autometallography, 10 min development) of iron in J-774 cells. Precipitated silver indicates location of iron under normal conditions, after endocytotic uptake or membrane adsorption. A Control cells showed only faint precipitates reflecting normal lysosomal heavy metals (mainly iron) present due to degradation (autophagocytotic) of metallo-organic compounds. B After $6 \mathrm{~h}$ in complete F-10 medium with $50 \mu \mathrm{mol} / 1$ $\mathrm{FeCl}_{3}$, followed by a $1 \mathrm{~h}$ rinse in the same medium, cells show heavy precipitates in a lysosomal pattern. C After $20 \mathrm{~min}$ exposure to $100 \mu \mathrm{mol} / 1 \mathrm{FeCl}_{3}$ in PBS silver precipitates (black arrowheads) are indicating the presence of iron bound to the plasma membrane. Magnification $(\mathrm{A}-\mathrm{C}) \times 1100$ 


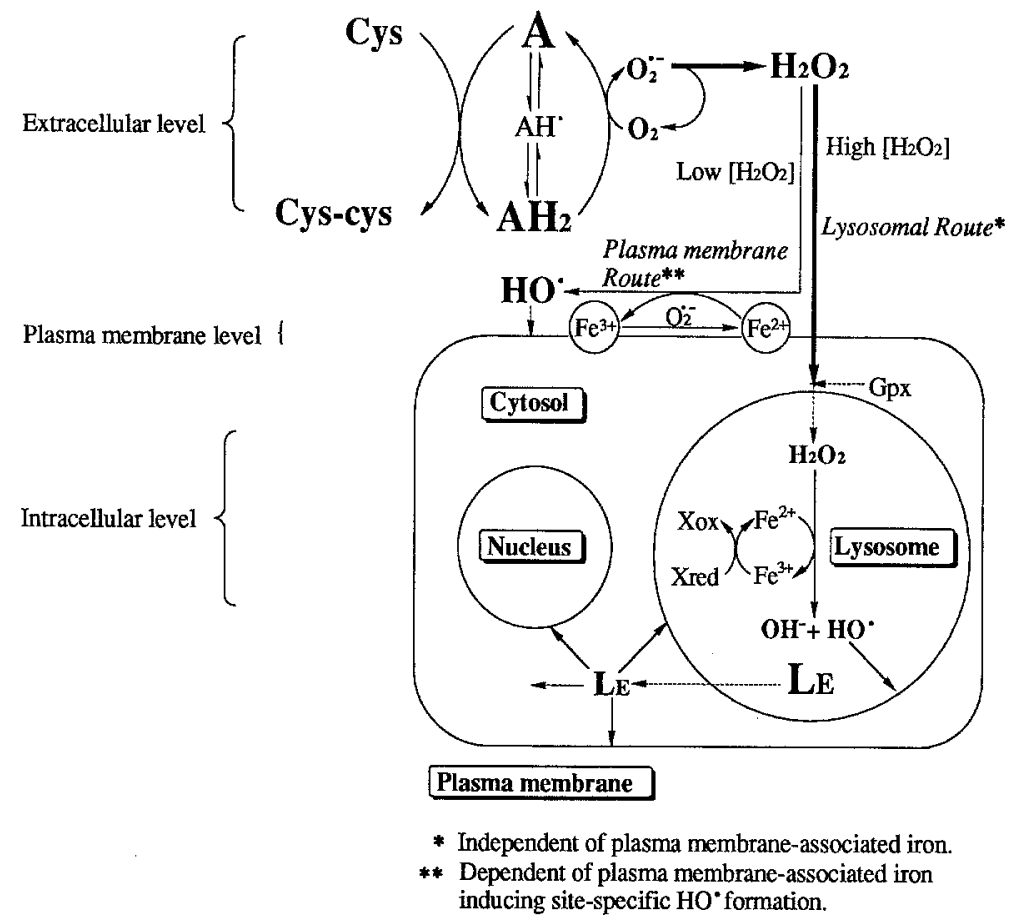

Fig.9. Summarizing scheme of mechanisms behind cytotoxicity of alloxan (A) and the reducing agent cysteine (Cys) at high and low concentrations. For detailed information of the chemistry, see the Introduction and Discussion sections. Hydrogen peroxide $\left(\mathrm{H}_{2} \mathrm{O}_{2}\right)$ is produced extracellularly and penetrates easily into the cells. Some of it may escape the antioxidative "shield", mainly glutathione peroxidase (Gpx) and catalase, and diffuse into lysosomes (Lysosomal route) where some reactive iron, reduced by intralysosomal redox systems (Xox $\rightleftharpoons$ Xred) e.g. cysteine or ascorbic acid, is always available which results in formation of hydroxyl radicals (HO-) due to Fenton reactions. Lysosomal membranes may then be damaged with leakage of hydrolytic enzymes (LE) and other lysosomal contents to the cytosol. If reactive iron is present close to the plasma membrane, Fenton reactions may take place site-specifically along the outer side of the plasma membrane with ensuing damage (Plasma membrane route). In the latter case alloxan and reducing agents, also in rather low concentrations can induce severe cell damage. Thus cells exocytosing iron in reactive form would be highly sensitive to alloxan transportation of iron to the plasma membrane, resulting in high local iron concentration during exposure to alloxan/Cys.

A summary of the alternative ways of cellular damage by alloxan and reducing agents resulting in high and low extracellular hydrogen peroxide concentrations, respectively, with or without plasma membrane-bound iron is given in Figure 9 suggesting that cells exocytosing iron may be particularly sensitive to alloxan.

Acknowledgements. We thank Ms. I.Svensson, Ms. K. Roberg and Mr. U. Johansson for expert technical assistance. This study was supported by the Swedish Medical Research Council, grant No. 4481 .

\section{References}

1. Webb JL (1966) Alloxan. In: Webb JL (ed) Enzyme and metabolic inhibitors vol. III. Academic Press, New York, pp 367-419

2. Rerup CC (1970) Drugs producing diabetes through damage of the insulin secreting cells. Pharmacol Rev 22: 485-518

3. Wellmann KF, Volk BW, Lazarus SS (1967) Ultrastructural pancreatic beta-cell changes in rabbits after small and large doses of alloxan. Diabetes 16: 242-251

4. Heikkila RE, Barden H, Cohen G (1974) Prevention of alloxaninduced diabetes by ethanol administration. J Pharmacol Exp Ther 190: 501-506

5. Heikkila RE, Winston B, Cohen G, Barden H (1976) Alloxan-induced diabetes - evidence for hydroxyl radical as a cytotoxic intermediate. Biochem Pharmacol 25: 1085-1092

6. Heikkila RE, Felicitas SC (1982) The prevention of alloxan-induced diabetes in mice by the iron-chelator detapac: suggestion of a role for iron in the cytotoxic process. Experientia 38: 378-379

7. Ishibashi $\mathrm{F}, \mathrm{Howard} \mathrm{BV}$ (1981) Alloxan and $\mathrm{H}_{2} \mathrm{O}_{2}$ action on glucose metabolism in cultured fibroblasts. Generation of oxygencontaining free radicals as a mechanism of alloxan action. J Biol Chem 256: 12134-12139
8. Harman AW, Fischer LJ (1982) Alloxan toxicity in isolated rat hepatocytes and protection by sugars. Biochem Pharmacol 31: 3731-3736

9. Sagström S, Scarlett SM, Sagulin G-B, Roomans GM (1987) Early effects of alloxan on rat submandibular gland. J Submicrosc Cytol 19: 555-559

10. Watala C, Budziejewska A, Jozwiak Z (1989) Alloxan-induced alterations in composition and dynamics of red blood cell membranes. I. Effect of alloxan on intact red blood cells and isolated erythrocyte membranes. Biochem Pharmacol 38: 17931798

11. Kawada T, Arakawa M, Kambara K et al. (1990) Oxygen radicals participate in alloxan-induced pulmonary edema. Proc XII Int Congr Electr Micr, Seattle, pp 298-299 (Abstract)

12. Zhang H, Zdolsek J, Brunk U (1991) Effects of alloxan and reducing agents on macrophages in culture. APMIS 99: 1038-1048

13. Zhang H, Gao G, Brunk U (1992) Extracellular reduction of alloxan results in oxygen radical-mediated attack on plasma and lysosomal membranes. APMIS 100: 317-325

14. Zhang H, Zdolsek J, Brunk U (1992) Alloxan cytotoxicity involves lysosomal damage. APMIS 100: 309-316

15. Lagercrantz C, Yhland M (1963) Free radicals in the reaction of alloxan with glutathione and ascorbic acid. Acta Chem Scand 17: $1677-1682$

16. Cohen G, Heikkila RE (1974) The generation of hydrogen peroxide, superoxide radical, and hydroxyl radical by 6-hydroxydopamine, dialuric acid, and related cytotoxic agents. J Biol Chem 249: 2447-2452

17. Deamer DW, Heikkila RE, Panganamala RV, Cohen G, Cornwell DG (1971) The alloxan-dialuric acid cycle and the generation of hydrogen peroxide. Physiol Chem Phys 3: 426-430

18. Grankvist K, Marklund S, Sehlin J, Täljedal I-B (1979) Superoxide dismutase, catalase and scavengers of hydroxyl radical protect against the toxic action of alloxan on pancreatic islet cells in vitro. Biochem J 182: 17-25

19. Fischer LJ, Hamburger SA (1980) Inhibition of alloxan action in isolated pancreatic islets by superoxide dismutase, catalase, and a metal chelator. Diabetes 29: 213-216

20. Winterbourn CC (1982) Superoxide dismutase-inhibitable reduction of cytochrome $\mathrm{c}$ by the alloxan radical. Biochem J 207 : $609-612$ 
21. Malaisse W (1982) Alloxan toxicity to the pancreatic $\beta$-cell. A new hypothesis. Biochem Pharmacol 31: 3527-3534

22. Thaete LG, Crouch RK, Buse MG, Spicer SS (1985) The protective role of copper-zinc superoxide dismutase against alloxan-induced diabetes: morphological aspects. Diabetologia 28: 677-682

23. Grankvist K, Marklund SL (1986) Effect of extracellularly generated free radicals on the plasma membrane permeability of isolated pancreatic $\beta$-cells. Int J Biochem 18: 109-113

24. Winterbourn CC, Cowden WB, Sutton HC (1989) Auto-oxidation of dialuric acid, divicine and isouramil. Superoxide dependent and independent mechanisms. Biochem Pharmacol 38: 611 618

25. Winterbourn CC, Munday R (1989) Glutathione-mediated redox cycling of alloxan. Mechanisms of superoxide dismutase inhibition and of metal-catalyzed $\mathrm{OH}$ - formation. Biochem Pharmacol 38: 271-277

26. Takasu N, Komiya I, Asawa T, Nagasawa Y, Yamada T (1991) Streptoxocin- and alloxan-induced $\mathrm{H}_{2} \mathrm{O}_{2}$ generation and DNA fragmentation in pancreatic islets. $\mathrm{H}_{2} \mathrm{O}_{2}$ as mediator for DNA fragmentation. Diabetes 40: 1141-1145

27. Starke PE, Farber JL (1985) Ferric iron and superoxide ions are required for the killing of cultured hepatocytes by hydrogen peroxide. Evidence for the participation of hydroxyl radicals formed by an iron-catalyzed Haber-Weiss reaction. J Biol Chem 260: 10099-10104

28. Malaisse WJ, Malaisse-Lagae F, Sener A, Pipeleers DG (1982) Determinants of the selective toxicity of alloxan to the pancreatic $\beta$ cell. Proc Natl Acad Sci USA 79: 927-930

29. Grankvist K, Marklund SL, Täljedal I-B (1981) CuZn-superoxide dismutase, Mn-superoxide dismutase, catalase and glutathione peroxidase in pancreatic islets and other tissues in the mouse. Biochem J 199: 393-398

30. Danner DJ, Brignac PJ, Arceneaux D, Patel V (1973) The oxidation of phenol and its reaction product by horseradish peroxidase and hydrogen peroxide. Arch Biochem Biophys 156: 759-763

31. Buffinton GD, Öllinger K, Brunmark A, Cadenas E (1989) DTdiaphorase-catalysed reduction of 1,4-naphthoquinone derivatives and glutathionyl-quinone conjugates. Biochem J 257: 561 571

32. Tennant JR (1964) Evaluation of the trypan blue technique for determination of cell viability. Transplantation 2:685-694

33. Grankvist K, Lernmark $\AA$, Täljedal I-B (1979) Trypan blue as a marker of plasma membrane permeability in alloxan-treated mouse islet cells. J Endocrinol Invest 2: 139-145

34. Rotman B, Papermaster BW (1966) Membrane properties of living mammalian cells as studied by enzymatic hydrolysis of fluorogenic esters. Proc Natl Acad Sci USA 55: 134-141

35. Dive C, Watson JV, Workman P (1990) Multiparametric analysis of cell membrane permeability by two colour flow cytometry with complementary fluorescent probes. Cytometry 11: 244252
36. Rundquist I, Enerbäck L (1985) A simple microcomputer system for microscope fluorometry. In: Mize RR (ed) The microcomputer in cell and neurobiology research. Elsevier, New York, pp335-353

37. Rundquist I, Olsson M, Brunk U (1984) Cytofluorometric quantitation of acridine orange uptake by cultured cells. Acta Pathol Microbiol Immunol Scand [A] 92: 303-309

38. Robbins E, Marcus PI (1963) Dynamics of acridine orange-cell interaction. I. Interrelationships of acridine orange particles and cytoplasmic reddening. J Cell Biol 18: 237-250

39. Timm F (1958) Zur Histochemie der Schwermetalle. Das SulfidSilberverfahren. Deut Z Gerichtl Med 46: 706-711

40. Brunk U, Brun A, Sköld G (1968) Histochemical demonstration of heavy metals with the sulphide-silver method. A methodological study. Acta Histochem 31:345-357

41. Brun A, Brunk U (1970) Histochemical indications for lysosomal localization of heavy metals in normal rat brain and liver. $J$ Histochem Cytochem 18: 820-827

42. Danscher G, Zimmer J (1978) An improved Timm sulphide silver method for light and electron microscopic localization of heavy metals in biological tissues. Histochemistry 55: 27-40

43. Starke PE, Farber JL (1985) Endogenous defenses against the cytotoxicity of hydrogen peroxide in cultured rat hepatocytes. $J$ Biol Chem 260: 86-92

44. Halliwell B, Gutteridge JM (1984) Oxygen toxicity, oxygen radicals, transition metals and disease. Biochem 18: 1-14

45. Halliwell B, Gutteridge JM (1985) The importance of free radicals and catalytic metal ions in human disease. Mol Aspects Med 8: $89-193$

46. Halliwell B, Gutteridge JM (1986) Oxygen free radicals and iron in relation to biology and medicine: some problems and concepts. Arch Biochem Biophys 246: 501-514

47. Starke PE, Gilbertson JD, Farber JL (1983) Lysosomal origin of the ferric iron is required for cell killing by hydrogen peroxide. Biochem Biophys Res Commun 133: 371-379

48. Zdolsek JM, Zhang H, Roberg K, Brunk UT (1993) $\mathrm{H}_{2} \mathrm{O}_{2}$-mediated damage to lysosomal membranes of J-774 cells. Free Rad Res Commun 18: 71-85

49. Zdolsek JM, Olsson MG, Brunk UT (1990) Photooxidative damage to lysosomes of cultured macrophages by acridine orange. Photochem Photobiol 51: 67-76

Received: 11 December 1992

and in revised form: 22 March 1993

Prof. U.T.Brunk

Department of Pathology II

Faculty of Health Sciences

University of Linköping

S-58185 Linköping

Sweden 